\title{
USING PERSONA DOLLS AS AN ANTI-OPPRESSIVE TECHNIQUE IN THE SOUTH AFRICAN SOCIAL WORK CURRICULUM
}

\section{Vivienne Bozalek, Carol Smith}

\section{THE CURRENT SOUTH AFRICAN CONTEXT}

The South African Constitution and Bill of Rights (1996) outlaws discrimination on the basis of race, culture, faith, gender and disability, etc. It addresses economic as well as human rights; however, we still live with discrimination, oppression and inequality. Xenophobic attacks have highlighted the seriousness of the levels of discrimination that persist in our country. South Africa is still a deeply divided and unequal society, where there is "race" and gender privilege plus deep-seated structural inequality.

The extent of poverty in South Africa is hotly debated, partly because no single official source provides reliable and regular trend data. According to the SA Institute of Race Relations, the percentage of South Africans living on less than $\$ 1$ a day doubled from about $4.5 \%$ to $8.8 \%$ between 1996 and 2005. The number of people in this category has expanded from 1.9 million to about 4.2 million (SAIRR Report, 2007).

According to the University of Stellenbosch, the number of people in South Africa living on less than R3 000 (about \$430) a year fell from 16.2 million to 15.4 million between 1993 and 2004. While the population grew $16.3 \%$ (or by 7.3 million people), there were fewer people living in poverty, both absolutely and relatively (Van der Berg, Burger, Burger, Louw \& Yu, 2006).

Human Sciences Research Council (HSRC) estimates show that the proportion of people living in poverty in South Africa and did not change significantly between 1996 and 2001. However, those households living in poverty have sunk deeper into poverty and the gap between rich and poor has widened (Altman, 2007). HIV and Aids continue to present major development, global health and security challenges. They reverse life expectancy gains, erode productivity, decimate the workforce, consume savings and dilute poverty-alleviation efforts. Women especially bear a disproportionate part of the Aids burden in Sub-Saharan Africa - the majority of people living with HIV are women $(61 \%)$. In Southern Africa $35 \%$ of all people are living with HIV. Mitigation of gender inequalities and the feminisation of the HIV epidemic continue to be one of the most needed strategic areas of intervention. But the lack of political will, limited capacity, restricted funding and weak institutions make integration a major challenge (UNAIDS, 2006). Children are stigmatised, bullied or excluded because of HIV status. Research suggests that stigma and discrimination can exacerbate psychological problems that children already experience in the HIV and Aids context (Deacon \& Stephney, 2007).

Refugees and xenophobia raise another concern about inequality. Most of South Africa's refugees come from countries such as the Democratic Republic of Congo, Zimbabwe, Burundi, Rwanda, Angola and Somalia. In the first five months of 2003 South Africa received 14000 new arrivals, bringing the total number of persons of concern to 90000 , comprising 24000 recognised refugees and 66000 asylum seekers. In some instances the increase in the number of refugees has created tensions with South African citizens, many of whom have blamed escalating crime and unemployment on illegal immigrants and refugees. Xenophobia has become a serious problem in some areas of the country (United Nations High Commissioner for Refugees UNHCR, 2004). Xenophobic attacks in 2010 have brought this issue to the fore. 
Many policies are in place to address these issues but they have yet to be implemented effectively. Policy measures such as the child support grant, early childhood development, the new schools curriculum, HIV and Aids, private maintenance and the expanded public works programme try to make an impact. These are issues of concern for social work practitioners and educators in South Africa, who need to develop effective ways to intervene in this context of inequality and oppression. There are several policy documents and educational strategies which have been developed to impact on these conditions.

\section{SOCIAL JUSTICE IN THE CONTEXT OF SOCIAL WORK EDUCATION}

The current social work education and training context is one which is informed by a concern with social justice and a focus on vulnerable and marginalised people. For example, the Bachelor of Social Work qualification emphasises issues of social justice, oppression and vulnerability, including the following:

- Skills to challenge structural sources of poverty, inequality, oppression, discrimination and exclusion;

- An understanding of, and the ability to demonstrate, social work values and the principles of human rights and social justice, while interacting with and assisting the range of human diversity;

- The understanding and ability to provide social work services directed towards protecting people who are vulnerable, at risk and unable to protect themselves (SAQA National Learners' Records Database Report Qualification: Bachelor of Social Work, 2003:1).

The Policy Guidelines for the Course of Conduct, Code of Ethics and Rules for Social Workers of the South African Council for Social Services (2007:6) of the echo the purposes expressed in the Bachelor of Social Work curriculum. The document charges social workers to challenge social injustices, pursue social change among vulnerable and disadvantaged groups, focus on issues of poverty, and strive to eliminate discriminatory practices on the basis of age, gender, race, ethnicity, sexuality, disability, language and socioeconomic status.

The values that guide the international curriculum are also those of social justice and respect for all, with social work practitioners and educators being charged to address and challenge inequalities and injustices and to facilitate the inclusion of marginalised, socially excluded and vulnerable groups of people (Global Qualifying Standards for Social Work Education and Training, 2005). This is also in line with the international definition of social work which states that "Principles of human rights and social justice are fundamental to social work" (International Definition of Social Work, 2001).

\section{ANTI-OPPRESSIVE AND ANTI-DISCRIMINATORY PRACTICE IN SOCIAL WORK}

Anti-oppressive/anti-discriminatory practice which has its precedents in radical, structural, feminist and anti-racist theoretical approaches has become the prevailing model in social work in the United Kingdom (Dalrymple \& Burke, 1995; Dominelli, 2002; Pollack, 2004; Thompson, 2003, 2006); Canada (Barnoff \& Moffat, 2007; Carniol, 1992; Coates, 1992; Mullaly, 2002; Razack, 2002); Australia and New Zealand (Fook, 1993; Healy, 2005; Pease \& Fook, 1999; Pease, 2002; Waldegrave, Tamases, Tuhaka, \& Campbell, 2003) and the USA (Finn \& Jacobson, 2003a, 2003b; Swigonski, 1996). The goal of anti-oppressive and antidiscriminatory practice is to promote social justice, transformation, equity and inclusivity by challenging various forms of oppression experienced by people who are differentially positioned. It does not privilege any one form of oppression, but sees them as intersecting. 
Furthermore, anti-oppressive practice transcends a focus on either the micro or the macro, encompassing both in its focus on personal and structural transformation.

Barnoff and Moffat (2007) observe that although the literature on anti-oppressive practice has proliferated in recent years, it has remained at an abstract theoretical level with little indication of how to practically implement this at an organisational or agency level. Sakamoto and Pitner (2005) concur with this perspective, arguing that anti-oppressive practice is too scholarly and ideologically driven and that it is difficult to actually translate into practice. Sakamoto and Pitner (2005) are also of the opinion that there is a lack of consensus on the concept of antioppressive practice and that this lack of clarity leads to a reluctance to practise anti-oppressive social work. The third problem with anti-oppressive practice, according to Sakamoto and Pitner (2005), who echo Payne's (1997) concerns, is that it does not focus specifically enough on micro-practice, but looks rather at macro-structural and organisational issues. They do not think that anti-oppressive practice offers enough direction to working with immediate problems of individuals and families.

An example of a more individual focus is Lena Dominelli's comprehensive work Antioppressive social work: theory and practice (2002), where she devotes a chapter to antioppressive practice work with individuals, and another to working with groups and collective action. She advocates the importance of anti-oppressive social workers being aware of their own identity positions so that they can locate themselves within the context of working relationships. She envisages anti-oppressive practice as being similar to that of Michael White's (2000) narrative therapy, in which dominant discourses are resisted and the social worker's task is the opening of "discursive spaces in which clients can develop their own interpretive story, that is, one that gives meaning to their experiences", and to understand how dominant discourses subjugate these stories and experiences (Dominelli, 2002:86). Antioppressive practice is regarded as a form of social justice which involves participatory parity in relationships between people, and improving social relations for marginalised and excluded people. Anti-oppressive practice goes beyond anti-racist or feminist social work (which focus on one particular oppression), but rather encompasses a complexity of power relations. Antioppressive values include interdependence, democracy and reciprocity.

\section{METHODOLOGY}

A qualitative case study approach was used. Case studies provide a holistic portrayal and detailed picture of student's experiences in relation to curriculum interventions (Marshall \& Rossman, 2006; Smith, 2009). Sources of data that were analysed included training reports, students' evaluations, and fieldwork placement reports. Consent was obtained from students to use their reports for this case study. We selected one student's report as emblematic of the application of the Persona Doll Approach (PDA) to oppressive practice.

\section{THE PERSONA DOLL APPROACH AS A FORM OF ANTI-OPPRESSIVE PRACTICE}

In an attempt to address the critiques raised by Barnoff and Moffat (2007), and Sakamoto and Pitner (2005) the Persona Doll Approach (PDA) provides an example of the practical implementation of anti-oppressive practice in the form of a particular technique that can be used in social work practice with individuals and groups to examine and address issues of identity, oppression and privilege. 
This article provides some indications of how the PDA can be used as a form of anti-oppressive practice. Our own definition of anti-oppressive practice is that it is based on a social justice approach to social work which uses a normative framework to assess whether people have access to resources (distributive justice), to ascertain the value ascribed to people's status/identity (recognition), and to address issues of inclusion and exclusion which relate to social belonging (representation) (Fraser, 2009). In our view, anti-oppressive practice looks at what people can be and do given the resources, their ascribed status or identity and whether they are socially included or excluded, and then examines how best to respond to the situation. An important aspect of anti-oppressive practice is that identities are seen as ascribed rather than natural and given. The major goals of anti-oppressive practice are to develop a consciousness of how people's circumstances are shaped by dominant political, economic and cultural discourses in society, and to develop mechanisms to challenge situations of inequality (MacDonald, 2006).

Anti-oppressive social work provides a means of looking at the impact of the political, economic and social context by deconstructing dominant cultural stories rather than defining problems in terms of pathological interpersonal relationships. Anti-oppressive practice looks critically at racist, sexist and ageist discourses that recruit blacks, women and children into submissive practices that denigrate them. It enables people to examine the ways in which various categories of people have been privileged or denied privileges, how they have been included or excluded, and how they have been able or not been able to flourish as human beings, rather than focusing on curing deficits defined by expert diagnoses.

\section{The Persona Doll Approach and its origins}

The Persona Doll Approach developed out of the work initiated by Kay Taus and Louise Derman-Sparks in the United States, and later was further developed by Babette Brown in the United Kingdom and in the Australian research of Glenda MacNaughton (Derman-Sparks, 2010; MacNaughton, 2005). Louise Derman Sparks (1989;2010) maintains that in societies where institutional structures create and maintain sexism, racism and able-ism, it is not enough to be non-biased, nor is it sufficient to be non-biased and just assume observer status; rather, one needs to actively intervene, challenge and counter personal and institutional behaviours that perpetuate oppression. The PDA provides the activist or social worker with a strategy and tool to deal with oppression.

Persona Dolls are used to help individuals and groups to develop empathy and to "unlearn" all types of prejudice. The PDA develops a strong sense self-worth and a secure cultural identity. This enables people to resist discrimination directed at them and to stand up for others experiencing oppression (Brown, 2001). The PDA has been influenced by the Australian researcher, Glenda MacNaughton, who applies a poststructural approach and engages with the politics of knowledge in order to create greater social justice and equity. Her position is that knowledge is inseparable from politics. She draws on Foucault, whose work explores relationships between knowledge, truth and power and the effects of these on our relationships and on our institutions. MacNaughton explores the concept of critical reflection "thinking deeply about what I do and why I do that" as it applies to teaching. Taking account of knowing why you make a decision, and why that particular decision and not one of the 100 other ways it was possible to act, and being mindful of who is advantaged and disadvantaged by the decision (MacNaughton, 2005). 
The sexist and racist power relationships that she observed in the play of Australian children also characterise play in many other societies, including South Africa, where sexist and racist relationships are woven into the fabric of society. MacNaughton (1999) undertook research using Persona Dolls to explore young children's understandings of indigenous Australians.

Persona Dolls were used with 4- and 5-year-old Anglo-Australian and Vietnamese-Australian children to find out whether the use of the dolls and their stories influenced how the children spoke about "race", class and gender. MacNaughton concluded that Persona Dolls, their stories and the conversations they initiate could illuminate the diverse and complex understandings young children are constructing about the social world around them. MacNaughton's work $(1999,2005)$ has inspired and influenced Persona Doll anti-oppressive work in both the UK and South Africa.

\section{Persona Dolls - an anti-oppressive tool for social work practice}

The South African Persona Doll training project has the dual focus of developing awareness and skills in adults, and in training adults how to use the approach with other adults, youths or children. The project responds to the expressed needs of social workers, teachers and trainers to assist in providing a practical way to address issues of prejudice.

The South African project works in urban and rural communities in disadvantaged areas of great poverty and in well-resourced middle-class areas. Bullying, exclusion, teasing linked to racism, sexism, xenophobia and HIV and Aids stigma are commonplace. The project addresses the need for psychosocial care and emotional literacy learning for young children and adults.

\section{How the Persona Doll Approach works}

Nelson Mandela said the following at his Presidential inauguration address in 1994:

No one is born hating another person because of their skin, or their background, or their religion. People must learn to hate, and if they can learn to hate, they can be taught to love. (Brown, 2001:xii)

The Persona Doll approach builds on his, and the African, belief in ubuntu (motho ke motho ka batho ba bang - a person is a person through other people) and universal and African traditions of storytelling to impart values of respect and humanity. The Persona Doll stories are taken a step further into problem-solving discussions, where children's and adults' voices are heard. The approach is a non-threatening way to address issues of gender, health and HIV/Aids, racism, disability, xenophobia, culture, language, faith, social class and poverty (Smith, 2009).

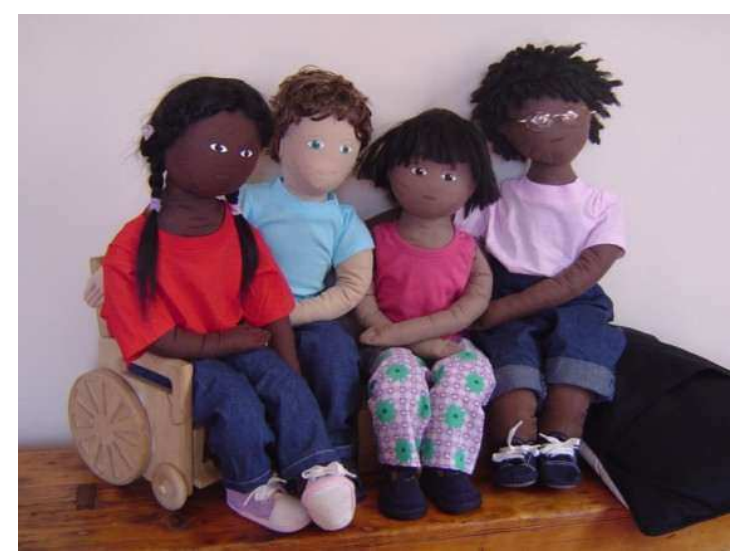

The cloth Persona Dolls are realistic looking, about $70 \mathrm{~cm}$ tall, and with various skin tones, hair and eye types and colours, they represent both genders and all ages. A Doll maybe plump or 
slim, be wheelchair users, wear spectacles, use a hearing aid, have a limb amputated, be scarred etc. Props are also used with the Dolls to represent a situation or life experience, for example, use of a bandage, no shoes, hearing aid, etc.

\section{Persona Dolls}

Adults or youths transform the Dolls into being "real" members of a group by giving them their own individual personalities, family and cultural backgrounds. The Dolls "visit" usually at a group time and the children or adults quickly accept them as friends. Through the scenarios of what has happened in their lives, the group shares the joys and sympathises with their problems. The group is given opportunities to say what they think and feel about issues or themes of prejudice and diversity, as well as creatively share ideas and options that could help to resolve the "problem" which identified in the scenario. Stories can be developed to build upon each other with the goal of encouraging children and adults to "unlearn" discriminatory attitudes and behaviour, while empowering them to stand up for themselves and for others and to challenge oppressive behaviour in a proactive way. Through this process problem-solving skills, empathy, language and emotional literacy are developed. At the same time the children's and adult's awareness of these issues is developed, self-esteem built up, life skills developed and negative attitudes challenged.

Young children are helped to understand the hurt that prejudiced attitudes and discriminatory behaviour cause and, crucially, to develop the skills they need to cope with bullying and exclusion. In the process they build on their understanding of fairness and unfairness, learn conflict management and problem-solving skills, and are encouraged to feel proud of their families and cultural backgrounds without feeling superior or inferior to others.

\section{The Persona Doll Project in South Africa: background}

The South African project has its origins in the Persona Doll anti-bias work in Europe and the United States. A network Diversity in Early Childhood Education and Training (DECET) was developed, and Persona Doll Training (PDT UK) was started by Babette Brown in 1999. Persona Doll anti-discrimination training, conferences, published materials and Persona Dolls are used by lecturers, social workers and teachers in the UK, Australia, Germany, New Zealand and Iceland.

In South Africa the PDA has been used to address psychosocial and emotional aspects of stigmas affecting children and adults, including forms of oppression related to HIV and Aids, racism, xenophobia, culture and language. Social workers, family and community motivators (FCMs), and teachers have expressed their need for practical assistance to deal with these problems (Smith, 2006). The project uses an experiential learning and participatory approach in training, including examining personal experiences of prejudice, critical reflection and problem solving. Training is designed to provide a non-threatening hands-on experience, raise awareness, and offer opportunities for reflection and discussion of diversity and oppression. Persona Dolls are the "tool" used to implement of the anti-oppressive approach.

\section{Example of this practice with UWC students}

A full-day training session was designed for the University of the Western Cape (UWC) social work and occupational therapy students. It was co-facilitated by two PDT anti-bias trainers (one English speaking and one Xhosa speaking) to accommodate the cultural diversity of UWC students.

The hands-on PDA workshop incorporates identity introductions, encouraging the group to think about their own identities and cultural backgrounds. The group agrees on ground rules to 
encourage trust, awareness of, respect for, feelings and opinions; and to listen actively and deal constructively with any conflict. Confidentiality is important as often deeply personal issues and feelings are shared. Small group discussion tasks were included to focus on personal experiences of discrimination and to help remember feelings that accompanied these experiences. This task ensures personal involvement as most people have had a personal experience of discrimination, even if they are from the dominant group. Aspects that the groups discusses include: What happened? How did you feel (what emotions)? What action was taken? Or no action? What were the obstacles that stopped people from acting?

Issues from the participants' feedback were used to lead the group into discussing the PDA. A Persona Doll was introduced in role to the group to encourage active participation. For example, "Nobuhle" was introduced:

Nobuhle is the name of this girl and she is 4 years old.

She speaks isiXhosa and her clan name is Mambhele.

She lives with her grandmother, uncle and cousins in a two-roomed shack. Her mother is working as a domestic worker far away from home. She shares a bed with her grandmother and another cousin.

Every night before they sleep, her grandmother would tell them a traditional story. She also attends pre-school in Khayelitsha near where she lives. After school or during weekends she would help her grandmother with household chores, especially washing dishes and laundry.

She also like to play hide and seek with her cousins and friends and shares with them her favourite meal "umgqusho". When they get tired of playing, she sometimes watches TV programmes, especially "Takalani Sesame”.

She doesn't like violencelfighting and is frightened of fire.

Nobuhle is not feeling happy today because one of her friends, Khanya, is very sick. She has been in hospital for the past two days. They have made and sent her a "get well" card.

After "meeting" the Doll, each small group has the opportunity to choose, after negotiating and deciding together, a Doll from the group on display and they create a persona for the Doll. While passing the Doll around, they decide on the following aspects as a group:

- Age;

- Gender;

- Cultural background;

- Faith or no faith;

- Language/s spoken and the Doll's name;

- Who the doll lives with (family structure);

- Where the doll lives: for example in a shack, house, flat, etc.;

- Where the doll sleeps: for example, bed, floor mat, double bunk, alone, with someone;

- Abilities and possible disabilities;

- Likes and dislikes: for example, play/games, sport, food, TV programmes;

- Fears: for example, the dark, big dogs, shooting sounds;

- Recent history: for example, newly arrived as a refugee; divorce, bereavement, new baby, new home, etc. 
Each group then introduces their Doll to the large group. Input is given on how to use the Persona Dolls and this is developed using demonstrations, viewing DVD footage of the Dolls in action with children and adults, and role plays and small group work.

Each group then creates a Persona Doll story/scenario for their Doll. As a group they develop a short story or introduction, based on a discrimination issue of what has happened to the Doll. For example: "Yesterday, as Timmy was walking to the shop...". The story is open ended: you do not "solve" the problem. This happens in the role-played discussion where options of how the problem could be resolved are shared, along with feelings to develop empathy, i.e. how would you have felt? How do you think Timmy feels? It may take many sessions and visits to "solve" the problem. The group records the story and members take turns to be the facilitator. Each group role-plays their scenario and receives constructive feedback from the facilitators, involving the large group in discussion as much as possible. Issues raised from the presentations are used to ensure clarity and understanding. The facilitators constantly build self-esteem and motivation. The workshop conclusion encourages people to try out this new non-threatening approach in dealing with often extremely difficult issues.

\section{STUDENT'S POST-TRAINING EVALUATION}

Students responses from their post-training evaluation forms indicate that many of them were excited by the new intervention technique; that they valued the facilitators' training approach; that they understood the value of their own empathy towards clients; they were aware of the need to practise and prepare the PDA thoroughly; they saw the value of exploring antioppression practices with colleagues across professions; they enjoyed the non-threatening interaction during the workshop; they had increased awareness of the importance of involving the clients in the process; they were highly motivated to try out the approach; they recognised the versatility of the Dolls regarding varied age groups, not only with children; and they understood the importance of exploring their own attitudes as social workers and occupational therapists. Some expressed initial reservations and wariness of the Dolls at first, but soon overcame the feeling. The need to tailor for adults - not to be too child focused - was also seen as important.

\section{ASSIGNMENT FOR PRACTICE}

The fourth-year social work students at UWC were required after the workshop to first do a simulated exercise and relate this to theory and then to apply the practice in their fieldwork placements. The students were first given a task after the workshop where they had to simulate a Persona Doll exercise, record it with an MP3 player and send a podcast of this recording to the assessor, together with an assignment. The exercise is shown below.

\section{PERSONA DOLLS ASSIGNMENT}

\section{A. Group Task}

- Create a persona for a Persona Doll using the guidelines given in the workshop. Write down the persona on the sheet provided.

- Identify the issue or topic you are dealing with, the goals for the session and who your target group will be. Plan the story or introduction you will use. Prepare a 10-15 minute session with the Doll. Identify the appropriate leading questions in which you encourage the naming of feelings, listening to each other, deep thinking, expressing ideas, 
empathising with the Doll so your group can help and advise it. Write down the issues, goals, target group, the story (introduction) and the questions you will ask.

\section{B. Individual Task}

Using the prescribed readings for this module, identify the theoretical approach and principles underlying the Persona Doll and identify the techniques which can potentially be used in this approach.

After the simulation the students are then given the opportunity to practise this technique in their fieldwork placement and are given the following task.

\section{REFLECTION ON ANTI-DISCRIMINATORY APPROACH}

You may use any anti-discriminatory techniques from theorists you have studied this year.

In your reflective piece, referring to your podcast, identify which techniques you have used, be critical of how you managed to implement them or not, and how useful they were in the particular context in which you are working.

\section{IF YOU ARE USING THE PERSONA DOLL APPROACH:}

Explain how you created a persona, using the guidelines from the workshop.

What were the appropriate leading questions that you used to get the individual/group to empathise with the doll?

What were the issues, goals, target, story (as introduction) and questions in your intervention?

Integrate your theory on anti-discriminatory practice reflecting on principles and techniques that you used in your intervention.

Use references and citations to indicate the theory you have used.

In the following section we outline the student's reflection of how the Persona Doll approach was applied by a fourth-year social work student in his fieldwork placement.

\section{A STUDENT'S REFLECTION}

The student was placed at a general hospital in the chemo- and radiotherapy ward for his fieldwork placement and his report is described below.

The student used the Persona Doll as a means of illustrating his competence at using antidiscriminatory practice at the mezzo-level. Below are listed the attributes of the persona of the student's Doll. Each of the Doll's attributes are followed by a brief discussion explaining the student's selection of the chosen attribute.

Age: 20 years. During initial interviews and also the screening process of the group members, the student found that the ages of patients newly admitted for either chemo- or radiotherapy was inconsequential. All patients, regardless of age, seemed to harbour sometimes surface and sometimes profound apprehension about either form of the treatment. A common anxiety was whether the treatment would actually make them worse rather than feel better. Here the reader should note that the group was diverse and varied significantly in terms of race, age, culture, language, creed, gender and number of treatment sessions experienced. What was lacking, however, was a young group member. The student therefore purposefully made "Nadine" (the Doll) 20 years old so that the group members who were on treatment longer could explain their 
experiences of the treatment so as to mitigate the young person's "anxieties" that many of the other group members were grappling with.

Gender: Female. Here unfortunately the student had no choice in ascribing a gender to the Doll as it was the only one available at the time. UWC has a selection of Persona Dolls for students to use in their fieldwork placements.

Cultural background: "Coloured", of Muslim faith. Nadine is an only child, originally from Cape Town, the city in which all of the group members resided. The reason for her being "coloured" was so that group members could better identify with her as the majority of the group's members were Afrikaans-speaking and "coloured", with the exception of one group member who was a Xhosa-speaking black woman. Nadine's religious spiritual beliefs were determined by there being only one Muslim member in the student's group. So as not to make this member feel excluded as one of the minority, the student attributed Islamic beliefs to Nadine. In retrospect the student would have changed Nadine's race to African-language speaking black South African rather than coloured, as the sole Xhosa-speaking member in the group, Monica, was marginalised in terms of language, culture and race. It soon emerged in the communication and interaction patterns that Monica was either patronisingly spoken to in loud, simple English, or totally dismissed.

Language/s: Afrikaans and English.

Name: Nadine Andrews.

Who the Doll lives with: Nadine has been living with her two year old daughter in Bonteheuwel until two months ago, when circumstances forced her to move in with her mother in Bridgetown.

Where the Doll lives: Nadine was living in a rented semi-detached home in Bontheuwel. The community of Bontheuwel is a predominantly "coloured" community on the Cape flats. Nadine lives here together with her 2-year-old daughter. Nadine however, did not always live in the community of Bontheuwel; she used to live in Bridgetown her entire life before deciding to move out on her own with her daughter.

Where Nadine sleeps: Nadine shared a double bed with her 2-year-old daughter in Bonteheuwel. All of the members in the group emanated from previously disadvantaged communities on the Cape Flats, one of whom had a daughter in a similar position to Nadine's. The reason for Nadine living in Bontheuwel is purely to convey empathy, it was more believable if Nadine lived in a community that shared similar social concerns to those of the group's members; this would bolster members' identification with Nadine, and also would add more credibility to the way she was feeling as a single mother, forced to resign from her job so as to attend chemotherapy.

Abilities/Disabilities: Nadine was diagnosed with cancer of the colon. All of the members in the student's group had some or other form of gastro-intestinal cancer. This would mean that they would not only be able to readily identify with Nadine's condition, but would also be able to provide her with accurate practical, social and psychological advice on how to cope (cognitively) with her illness.

Likes and dislikes: Nadine enjoys spending time with her daughter. She thoroughly enjoys time spent at the park with her daughter. Her favourite season is summer as this would permit her to spend ample time outdoors with her daughter. Nadine used to like spending free time with her friends, but this is now no longer possible because, since her daughter's birth, all of her free 
time is spent tending to her daughter. Her friends are also single with no children to care for. Nadine says she no longer has the time to be young, because she now has not only the responsibility of caring for her daughter, but also for herself. Nadine's favourite food is Italian; she enjoys any dish prepared with pasta. She describes herself as a being an outgoing person before the birth of her daughter, but no longer has time for herself to do the things she used to enjoy before her daughter's birth. Amongst the things she enjoyed most were going clubbing with her friends, watching movies at the cinema (her favourite type of movies being comedies), and spending weekends visiting friends or relatives.

Television programmes: Soap operas and talk shows. Nadine is an avid soap opera viewer. She loves Sewende Laan, The Bold and the Beautiful, and Days of our Lives. ${ }^{1}$ Her favourite talk show is Oprah.

Fears: Currently Nadine says her biggest fear is dying and not knowing what would happen to her daughter. Nadine also fears spiders and heights.

Recent history: Nadine has recently moved in with her 46-year-old widowed mother in Bridgetown. Nadine's mother is unemployed and receives a disability grant. They all reside in a two-bedroom semi-detached home furnished with all amenities. Nadine has been living with her mother for the past two months, since she is no longer able to afford the pay the rent in her home in Bontheuwel as a result of her no longer being able to work (because of her cancer and having to receive prolonged chemotherapy treatment). Nadine says that she hates living with her mother, as her mother constantly nags about there not being enough food, how she regrets having a daughter as then Nadine falling pregnant could have been avoided. Since making contact with the social worker at Groote Schuur hospital, an application has been lodged for a temporary disability grant for Nadine. Nadine was screened by the social worker and admitted to the therapy group as she stated that she was not coping well with her illness and feared the treatment. Many of Nadine's concerns revolved around her losing her autonomy, being overly dependent on her mother for everything, the material welfare of her daughter, her changing identity from being a young 20-year-old woman to a now ill person "cursed" with cancer. Finally, Nadine lacks psychosocial support and feels that she is unable to cope practically with her diagnosis.

\section{Some of the leading questions used to get group to empathise with Nadine}

The theme for this session was the consideration and importance of fulfilling practical/physical tasks in coping with cancer. However, some of the questions put to group members during the preceding or subsequent sessions will be presented. Furthermore, with this theme the student hoped to explore some of the practical things members can do - for example, how to regulate discomfort or pain, and how to become comfortable with having to cede tasks to a relative or immediate family member that they used to be able to complete on their own, and how to deal with feelings of guilt and being burdensome to loved ones.

Issues, goal, target

The main issues the student endeavoured to cover with the use of the Persona Doll were the changing identities of persons afflicted with cancer, mainly in terms of gendered role expectations, coping with the illness, and death and dying. The goals for the group work programme were decided upon by both the student and the group's members. The goals

\footnotetext{
${ }^{1}$ Popular South African and US TV programmes.
} 
included increasing members' coping capacity, taking responsibility for their illness, working through emotions and cognitions preventing them from coming to terms with their diagnoses, and acceptance. The introductory story is outlined below.

\section{Session introduction}

Nadine says that she does not feel like doing anything, she doesn't find pleasure in doing anything. She would like to know whether it is normal to feel this way, because she sometimes feels likes she is the only person feeling this way and it makes her feel terrible.

Nadine would like to know what you do when you sometimes feel this way.

Nadine says she hates her mother having to do certain things for her. Her mother generally does not complain, but Nadine sometimes feels that she is a burden to her mother. Nadine wants to know how you experienced going from being an independent person to one who is extremely dependent on others for assistance.

Even though she has been told of the different forms of treatment, Nadine is fearful that going on and staying on the treatment might result in her becoming worse than she presently is. Nadine asks whether you had the same fears, and what you did to get rid of them?

Nadine thinks that Monica (the only black member in the group at that stage) is extremely silent and a bit left out of the discussion. She would like to know what Monica thinks about the topic Elizabeth raised?

\section{The student's reflection on the use of the PDA in anti-discriminatory practice}

In social work anti-discriminatory practice refers to the mitigation or "elimination of discrimination and oppression, specifically in terms of challenging sexism, racism, ageism and ableism, and other forms of discrimination and oppression encountered in social work" (Thompson, 2006:33). Thompson further cautions practitioners against making "stereotypical assumptions", which he contends perpetuate and further entrench oppression and discrimination rather than challenging them.

The student did not enter the group with the assumption that group members were discriminated against as a result of their illness. He used the Persona Doll to explore whether group members felt they were discriminated against and asked: "Nadine wants to know whether you are being at all treated differently by your family, friends, or neighbours after disclosing your disease?" From this leading question it soon emerged that members felt they were being "babied" by family members and neighbours and seen as being less competent. So as to ensure that group members felt that the student himself was not also fitting them into the narrow category of being "typically disabled persons", he allowed them to decide what themes were relevant or not to be included in the programme. Thompson (1993:19) contends that traditional social work approaches, particularly in response to persons with disabilities, "mask the inherent marginalisation and dehumanisation involved in policies in relation to people with disabilities", which to some degree permits or legitimates the discrimination or oppression as normal, more aptly described as disableism (Carniol, 1992). As at the individual level traditional case work, which was heavily influenced by psychodynamic approaches, "explained" the disabled client's frustration, depression, guilt or shame in terms of innate unconscious or subconscious drives, or ego defence mechanisms (Allen, 2006) that suggests individual pathology rather than implicating oppressive structures affirmed by social policies aimed at maintaining the status quo (Thompson, 1993:19). 
In the group setting, however, open discussion about members' feelings associated with their disabilities brings about some form of normalisation about, for example, feeling depressed, helpless or frustrated over the way they get treated as patients by medical staff and social workers. An explicit link between organisational policies and patient response can be made.

To explore and elicit sentiments about how members felt about the way in which they were treated at the hospital, Nadine told the group about her experience at a former hospital (the referring hospital) and asked group members to tell them how they were treated at Cape Town Hospital, $^{2}$ as this was her first time being treated at this medical facility. In response to Nadine's question, members seemed to agree that staff at the hospital "treat us like we're not really people; they just see the illness [instead of the person], and tell you what's wrong with you. And who are we to argue with them, they are the doctors, the ones trained to 'fix' us? All we can do is trust them. When I had a job and went to the doctors on my medical aid, I got much better treatment."

The student, after listening to Nadine's and the other group members' thoughts, attempted to link the policies at their public hospital and the cost of the treatment to their disabilities. For example, patients have to conform to strict medical criteria in order to be admitted to various treatment programmes. This contributed to their feelings of frustration and sometimes being treated in a way they felt they did not deserve. One of the group's members said: "If pretending to be very sick and to be a little smaller than the doctors is going to get me treated for cheaper, and I was, I'm going to do it." Here, the perception that the more patients conform and submit to medical criteria and medical staff in powerful positions (translated into procedures governing their acceptance into treatment programmes), the more policies that explicitly discriminate against any person diagnosed with an illness or disability are legitimised. Where the failure to receive services precipitates feelings of anger, frustration over poor service delivery and selfblame for failing to get into the programme, anti-discriminatory practice has a clear place.

\section{CONCLUSION}

The above case study is an instance of the successful translation of anti-oppressive theory into practice using the Persona Doll Approach. It clearly illustrates that Barnoff and Moffat's (2007), and Sakamoto and Pitner's (2005) concerns about the lack of practical application of anti-oppressive social work can be addressed through the use of such approaches as the PDA. Furthermore, the case study demonstrates that the PDA is not only applicable to children and youths, but can be used successfully with adults facing various forms of discrimination and trauma. The issues which were brought to the fore by the scenario which the student sketched through the doll included the difficulties in accessing resources (access to cancer treatment and hospital services) and the values ascribed to people's status/identity (the status in the family of the person who is living with cancer, and in the group setting), as well as issues of inclusion and exclusion which relate to social belonging (the Xhosa-speaking person's marginalisation, not being able to live in her own home and community). The student's account also demonstrates how the PDA could be used to challenge the normalisation of dominant discourses, and allow service users alternative ways of viewing their predicaments. Furthermore the student's report on his experience highlights the usefulness of this approach in providing a safe and non-threatening environment where service users can voice their concerns and give an account of their personal experiences of oppression, exclusion and discrimination.

\footnotetext{
${ }^{2}$ A pseudonym for the hospital at which the student was placed.
} 


\section{RECOMMENDATIONS FOR FURTHER INTERVENTION AND RESEARCH}

The Persona Doll Approach is a useful tool in the Social Work curriculum that addresses issues of identity, oppression, marginalisation and exclusion. The students' responses to the PDA training sessions and to the fieldwork placement indicated that the training and the use of the PDA had increased their awareness of diversity and prejudice. However, they also highlighted the need for more and deeper work around these issues. Social work students need to further explore their attitudes to diversity and develop personal empathy towards difference; this is not a "quick-fix" solution or one-off experience, but needs ongoing work. More time in the curriculum could be allocated to dealing with empathy, identity and the assumptions we make about other people and discrimination issues.

The PDA has been successfully researched in other countries, but there is a need for South Africa experience to be documented and shared. In addition, specific issues (gender, race and class) need to be researched in greater depth to ascertain the usefulness of the PDA as a practical approach to inform anti-oppressive practice in South Africa. This would be in line with international and South African imperatives in policy and curricula to address issues of social injustice, discrimination and exclusion.

In conclusion, the Persona Doll Approach offers a practical technique for social work educators and practitioners to incorporate and implement a social justice perspective. We contend that it is beneficial not only for students and clients, but also for educators and practitioners themselves to interrogate their own assumptions and levels of empathy regarding difference and discrimination.

\section{REFERENCES}

ALTMAN, M. 2007. Employment growth and development initiative report. Pretoria: Human Sciences Research Council.

BARNOFF, L. \& MOFFAT, K. 2007. Contradictory tensions in anti-oppressive practice in feminist social services. Affilia, 22(1):56-70.

BROWN, B. 2001. Combating discrimination, persona dolls in action, UK \& US: Trentham Books.

CARNIOL, B. 1992. Structural social work: Maurice Moreau's challenge to social work practice. Journal of Progressive Human Services, 3(1):1-20.

COATES, J. 1992. Ideology and education for social work practice. Journal of Progressive Human Services, 3(2):15-30.

DALRYMPLE, J. \& BURKE, B. 1995. Anti-oppressive practice: social care and the law. Buckingham: Open University Press.

DEACON, H. \& STEPHNEY, I. 2007. HIV/Aids, stigma and children. Pretoria: Human Sciences Research Council.

DERMAN-SPARKS, L. \& The ABC Task Force. 1989. Anti-bias curriculum. Tools for empowering young children. Washington, DC: National Association for the Education of Young Children.

DERMAN-SPARKS, L.\& OLSON-EDWARDS, J. 2010. Anti-bias education for young children and ourselves. Washington, D.C.: National Association for the Education of Young Children. 
DOMINELLI, L. 2002. Anti-oppressive social work: theory and practice. Basingstoke: Palgrave.

FINN, J. \& JACOBSON, M. 2003a. Just practice: steps towards a new social work curriculum. Journal of Social Work Education, 39(1):57-78.

FINN, J. \& JACOBSON, M. 2003b. Just practice: a social justice approach to social work. Iowa: Eddie Bowers Publishing Co.

FOOK, J. 1993. Radical casework: a theory of practice. New South Wales: Allen and Unwin.

FRASER, N. 2009. Scales of justice reimagining political space in a globalizing world. New York: Columbia University Press.

GLOBAL SOCIAL WORK STANDARDS. 2005. [Online] Available: http://www.ifsw.org.

HEALY, K. 2005. Social work theories in context: creating frameworks for practice. Basingstoke: Palgrave MacMillan.

INTERNATIONAL DEFINITION OF SOCIAL WORK. 2001. [Online] Available: http: //www.iassw.soton.ac.uk

MacDONALD, C. 2006. Challenging social work: the institutional context of practice. Basingstoke: Palgrave MacMillan.

MacNAUGHTON, G. \& DAVIS, K. 2001. Beyond 'othering': rethinking approaches to teaching young Anglo-Australian children about indigenous Australians. Contemporary Issues in Early Childhood, 2(1):153-169.

MacNAUGHTON, G. 1999. Dolls for equity: young children learning respect and unlearning unfairness. Paper presented at the Persona Doll conference, London, UK.

MacNAUGHTON, G. 2000. Rethinking gender in early education. California: Sage Publications.

MacNAUGHTON, G. 2005. Doing Foucault in early childhood studies. New York: Routledge.

MacNAUGHTON, G., ROLFE, G.A. \& SIRAJ-BLATCHFORD, I. 2001. Doing early childhood research. London: Open University Press.

MARSHALL, C. \& ROSSMAN, G.B. 2006. Designing qualitative research $\left(4^{\text {th }} \mathrm{ed}\right)$. Thousand Oaks: Sage Publications.

MULLALY, B. 2002. Challenging oppression: a critical social work approach. Ontario: Oxford University Press.

PAYNE, M. 1997. Modern social work theory $\left(2^{\text {nd }}\right.$ ed). Basingstoke: Palgrave McMillan.

PEASE, B. \& FOOK, J. (eds) 1999. Transforming social work practice: postmodern critical perspectives. London and New York: Routledge.

PEASE, B. 2002. Rethinking empowerment: a postmodern appraisal for emancipatory practice. British Journal of Social Work, 32:135-147.

POLLACK, S. 2004. Anti-oppressive social work practice with women in prison: discursive reconstructions and alternative practices. British Journal of Social Work, 34:693-707. 
RAZACK, N. 2002. Transforming the field: critical antiracist and anti-oppressive perspectives for the human services practicum. Halifax: Fernwood Publishing.

SA INSTITUTE OF RACE RELATIONS. 2007. SAIRR Report.

SAKAMOTO, I. \& PITNER, R. 2005. Use of critical consciousness in anti-oppressive social work practice. British Journal of Social Work, 35:435-452.

SMITH, C. 2006. Persona dolls: making a difference. Cape Town, PDT and Western Cape Education Department Publication.

SMITH, C. 2009. Persona dolls and anti-bias curriculum practice with young children: a case study of early childhood development teachers. Cape Town: University of Cape Town. (Unpublished MA Dissertation)

SOUTH AFRICAN COUNCIL FOR SOCIAL SERVICE PROFESSIONS. 2007. Policy Guidelines for the Course of Conduct, Code of Ethics and Rules for Social Workers. [Online] Available: http://www.sacssp.co.za.

SOUTH AFRICAN QUALIFICATIONS AUTHORITY. 2003. National Learners' Records Database Report. Qualification: Bachelor of Social Work. [Online] Available: http: //www.SAQA.org.za.

SWIGONSKI, M.E. 1996. Challenging privilege through Africentric social work practice. Social Work, 41(2):153-161.

THOMPSON, N. 1993. Anti-discriminatory practice. Basingstoke: Palgrave MacMillan.

THOMPSON, N. 2003. Promoting equality: challenging discrimination and oppression. Basingstoke: Palgrave MacMillan.

UNAIDS. 2006. Aids epidemic update, December.

UNITED NATIONS DEVELOPMENT PROGRAMME. 2004. Human Development Report. UNITED NATIONS HIGH COMMISSIONER FOR REFUGEES (UNHCR). 2004. Report.

VAN DER BERG, S., BURGER, R., BURGER, R., LOUW, M. \& YU, D. 2006. Trends in poverty and inequality since the political transition. Working Paper 06/104 Development Policy Research Unit (DPRU).

WALDEGRAVE, C. TAMASES, K.; TUHAKA, F. \& CAMPBELL, W. 2003. Just therapy a journey. Adelaide: Dulwich Centre Publications.

WHITE, M. 2000. Reflections on narrative practice: essays and interviews. Adelaide: Dulwich Centre Publications.

Prof Vivienne Bozalek, University of the Western Cape, Bellville; Ms Carol Smith, Personal Doll Training, SA., South Africa. 